\title{
VOCABULARY LEARNING STRATEGY EMPLOYED BY HIGH- ACHIEVER UNIVERSITY STUDENTS AT MALANG
}

\author{
Zizhi Meyretha Putri. ${ }^{1}$, Erly Wahyuni ${ }^{2}$ \\ English Language Education Department, University of Muhammadiyah Malang- \\ Indonesia ${ }^{1}$; English Language Education \\ Department, University of Muhammadiyah Malang- Indonesia ${ }^{2}$ \\ zizhi.meyretha@gmail.com;
}

\begin{abstract}
Learners should learn English language basic skills and also the components such as grammar, pronunciation, and vocabulary. The learners will have a difficulty in understanding interlocutor's mean or expressing their ideas without having a sufficient vocabulary. In learning vocabulary, students may have various strategies used to improve their vocabulary. High-achiever students are considered as students who perform well in school and have a high academic achievement. This research is conducted to find out the most common strategy in learning vocabulary used by high achiever students and the reasons in choosing the strategy. Mixed methods, which combine quantitative and qualitative research design was applied for this research. Then, the instruments of this research are questionnaire and interview. The researcher takes seventh-semester highachiever students as population and 26 high-achiever students who have Grade Point Average (GPA) 3, 51 - above were taken as the sample of this research. The result showed that the most common strategy employed by high-achiever student is cognitive strategy with mean score of 79.8. The strategies involved were note-taking, highlighting, analyzing, dictionary-use, etc. The high-achiever students preferred to use cognitive strategy because it helped them in learning English skill, easy to apply, to make them speak English well, effective and also it is comfortable to use during learning process Therefore, appropriate learning strategies would help the students perform their English well.
\end{abstract}

Keywords: learning strategy, vocabulary, high achiever

\section{INTRODUCTION}

Along with the advance of the era into the era of globalization, English as an international language helps us in touch with the other side of the world. Therefore, in Indonesia, all students are expected to master English language very well. To master English language well, learners should learn English language basic skills and also the components. According to Oxford (1990), generally, English language skills are divided into four modalities; receptive skills (listening and reading), and productive skills (speaking and writing). The components of English language include phonology, pragmatics, semantics, and syntax. These components are known as grammar, pronunciation, and vocabulary.

As stated by Alqahtani (2015), vocabulary means the number of words which are needed to convey ideas and utter the meaning of the speaker's

CELTIC: A Journal of Culture, English Language Teaching, Literature \& Linguistics ISSN: 2356-0401, E-ISSN: 2621-9158, VOL. 6, NO. 1, June 2019. 
substance. Vocabulary is essential to English language because without having a sufficient vocabulary, the learners will have a difficulty in understanding others' mean or expressing their ideas. Therefore, the use of strategy in learning vocabulary is an important thing in order to assist student's vocabulary mastery.

For the teacher, the use of strategy can facilitate and stimulate the interests of students' in learning English. In addition, Leeke and Shaw (as cited in Hashemi and Hadavi, 2014) emphasized that having an effective strategy in learning vocabulary is very important for learners. The learners will be more interested in learning because they can choose the learning strategy that suits them. O'Malley and Chamot (as quoted in Hardan, 2013) defined strategies are the thought and behavior that learners use to help them comprehend, learn, or retain information. Thus without the strategy, the learners will face difficulties in gaining the knowledge or information which they need to learn.

Learning strategies may help learners overcome the language task difficulties to improve their learning. Then, Cameron (as cited in Boonkongsaen, 2012) states that vocabulary learning strategy helps the learners to understand and remember vocabulary items. In learning English vocabulary, the choice of vocabulary learning strategy determines the success of the English vocabulary mastery which will impact on the increase of their communication skills.

High-achiever students are considered as students who perform well in school and have a high academic achievement(Zohar et.al, 2001). Also, stated in Burrow, et.al (2012), high achiever can be identified succinctly by his or her strong GPA, which means the students in the class who are considered as high achievers can be identified by the GPA score. Hence, the high achiever students who are good in academic and have high GPA score develop their own effective and efficient strategies which suit themselves in the learning process to acquire better achievement.

The researcher chose to analyze high-achiever students in order to make this research as a reference for usual students to employ learning vocabulary strategy as same as high achievers students.in addition, the purpose of this study is to find out the most common strategy in learning vocabulary used by highachiever students and the reasons in choosing the strategy.

\section{Learning Strategies}

Generally, learning means the process of acquiring a knowledge or skill by studying, practicing, or experiencing. Brown (2007:119) defined strategy as "a specific way that can be employed to approach a task or problem, modes to achieve a particular end and a design for controlling particular information." In other words, a strategy is an action that is used to achieve a success or accomplish objectives. In learning, strategies can be described as the tool to gain the goals of

CELTIC: A Journal of Culture, English Language Teaching, Literature \& Linguistics ISSN: 2356-0401, E-ISSN: 2621-9158, VOL. 6, NO. 1, June 2019. 
the learning process. Therefore, it can be concluded that learning strategies are the learner's way or the approaches that are used to achieve the objective of learning or assist the learning process.

\section{Classification of Strategies}

Oxford (1990) has different learning strategies taxonomy as follows. There are direct strategies and indirect strategies. Direct strategy means that it directly involved with the target language. The group of direct strategies is memory strategy, cognitive strategy, and compensation strategy.

Memory strategies assist learners in storing and obtain new knowledge, It involves grouping, associating or relating a piece of information to another, placing new words into a context, using imagery, using keywords, representing sounds in memory, structured reviewing, using physical response or sensation, and using mechanical techniques.

In cognitive strategies practicing strategies is among the most important strategies. The cognitive strategies involve practicing, receiving and sending messages, analyzing and reasoning, taking notes, summarizing, and highlighting.

Then, the last strategies of direct strategies are compensation strategies. Compensation strategies are aimed to form enough supply of grammar, especially vocabulary. It consists of guessing intelligently in listening and reading and overcoming limitations in speaking and writing.

Moreover, the indirect strategies support language learning without directly involving the target language. The strategies are divided into three: metacognitive, affective, and social. In metacognitive strategies, the learners allow to make their own understanding using centering, arranging, planning and evaluating. For centering the material the learners able to apply some of the strategies which are associating with an already known material, paying attention to language learning task, and delaying speech production to focus on listening. For planning to get the most out the learning material the learners can use several strategies such as finding out about language learning, organizing the schedule and the environment, setting goals and objectives, deciding the purpose of typical language task involving the four English skills, planning for a task, finding the time to practice. In evaluating the planning, the learners can evaluate themselves by using strategies which are included observing and learning from errors and evaluating the learners' overall progress.

Affective strategies support the learners in term of emotion, motivations, and attitudes. The affective strategies can be identified by lowering the anxiety, encouraging themselves, and taking the emotional temperature.

CELTIC: A Journal of Culture, English Language Teaching, Literature \& Linguistics ISSN: 2356-0401, E-ISSN: 2621-9158, VOL. 6, NO. 1, June 2019. 
Lastly, social strategies assist students to learn through interaction with others. There are three sets of social strategies, such as asking questions, cooperating with others, and empathizing with others.

\section{Vocabulary}

Vocabulary means the number of words which are needed to convey ideas and utter the speaker's meaning(Alqahtani, 2015). It is one of the English language components that support the speaking, reading, writing, and listening skill. Even by mastering the grammatical form, the learner will not be able to communicate in a foreign language without mastering the vocabulary. Therefore, having a large vocabulary will help the learners to express the idea precisely when communicate.

Nation (2001) states that the number of words that are needed by the reader to comfortably read and comprehend the un-simplified text is 3,000 words minimum. Meanwhile, to be able to write an essay, it takes about 2,000 to 3,000 vocabulary added with a number of academic words or written material related to the aim of the writing.

All in all, it is very important to learn and understand vocabulary in learning English language, because by learning, understanding, and memorizing the vocabulary of English language, the students are expected to apply the vocabulary in speaking, communicating, or comprehending a text.

\section{High Achiever}

According to Burrow, et.al (2012), high-achiever students can be identified succinctly by his or her strong Grade Point Average (GPA). The GPA determines the standardized way for a college to evaluate the student's academic virtue. According to chancellor's decision on academic regulations (Number 15, 2010), the accumulative grade point average divided into three: satisfactory with2.00-2.75, very satisfactory with 2.76-3.50, and cum laude with 3.51-4.00. Therefore, the researcher conceives that the students who have strong or high GPA are those who are included in a cum laude group. As also stated in English for Specific Purposes (ESP) Transcript, qualification of cum laude can be achieved if the student has 3.51 or higher GPA. Besides, the students who perform well in school and have high academic achievement also considered as students who are high achieving in learning(Zohar et.al, 2001). Moreover, the high achievers have better study orientation, have study habits, and attitude(Sarwar, et.al, 2009). 


\section{METHOD}

Due to this research, the researcher ascertains to use mixed methods. The researcher applied these research designs because the researcher involved the analysis of both data forms. As stated by Creswell (2014), mixed method combines elements of qualitative and quantitative approaches which makes mixed method presents between them. Moreover, according to Angrosino (2007:1), "qualitative research tries to understand the details of an event or action in order to found the meaning, definition, concept, characteristic, and descriptions. Based on this research, the qualitative research design would be able to answer what strategies are employed by the high achiever students in learning vocabulary including the reasons for choosing the strategies. On the other hand, quantitative research helped the researcher to find the most common strategy by calculating the mean score of the questionnaire answers.

The population of this study was the high-achiever students of a university in Malang. The total number the students at seventh-semester was 213 students. In this study, the researcher took students who had GPA 3.51 and above. There were 103 students that considered as high achievers. The researcher used purposive sampling because she needed typical criterion in order to achieve the goal of the research. According to Arikunto (2010), if the population is less than 100, all of the population is taken as the sample. If the population is more than 100 , the researcher can take $10 \%-15 \%$ or $20 \%-25 \%$ or more of the population as the sample. Based on the statement above, the researcher took $25 \%$ of the population (103 students) that was 26 high achiever students.

To get the data in a research, closed-ended questionnaires (adapted from Waskito, 2005) were employed. The questionnaires dig out learning strategy and Oxford's theory about learning strategy and a semi or partially structured interview as the instruments for this research.

\section{Procedure}

In collecting the data, the researcher applied five steps: (a) distributing the questionnaires by using google form for 26 high-achiever students in the academic year 2015-2016, (b) completing the questionnaire and collects the data from the entire participants, (c)confirming the participants' response to the questionnaire also to identify the reason for choosing the strategy by conducting the interview, (d) noting down all the important points related to the reason of choosing the strategy in learning vocabulary, (e) interpreting the result of the interview. In data analysis, the researcher organized some procedures as follows; (a) tabulating the students' questionnaire data,(b) calculating the students' questionnaire data, (c) formulating the result $M=\frac{\Sigma x}{N}$ (M: mean score, $\mathrm{X}$ : total 
score, $\mathrm{N}$ : number of the items), (d) describing the result of the study,

(e)concluding the result of the study.

\section{FINDINGS AND DISCUSSION}

Findings

\section{The Most Common Strategy in Learning Vocabulary Employed by High Achievers Students}

In this research, there are six learning strategies; memory strategy, cognitive strategy, meta-cognitive strategy, affective strategy, social strategy and compensation strategy (Oxford, 1990). The result of questionnaire about the most common strategy used by high achiever students can be seen below.

Table 1. The Most Common Strategy in Learning Vocabulary Employed by High-achiever Students

\begin{tabular}{|c|c|c|c|c|c|c|c|c|c|c|c|}
\hline \multirow{3}{*}{$\begin{array}{l}\text { Learning } \\
\text { strategies }\end{array}$} & \multirow[t]{3}{*}{ Items } & \multicolumn{8}{|c|}{ Scores } & \multirow{3}{*}{$\begin{array}{l}\text { Total } \\
\text { score }\end{array}$} & \multirow{3}{*}{ Means } \\
\hline & & \multicolumn{2}{|c|}{ Always } & \multicolumn{2}{|c|}{ Often } & \multicolumn{2}{|c|}{ Sometimes } & \multicolumn{2}{|c|}{ Never } & & \\
\hline & & $\mathrm{Nm}$ & Scr & $\mathrm{Nm}$ & Scr & $\mathrm{Nm}$ & Scr & $\mathrm{Nm}$ & Scr & & \\
\hline Memory & 1 & 1 & 4 & 15 & 45 & 10 & 20 & 0 & 0 & \multirow[t]{6}{*}{349} & \multirow[t]{6}{*}{69.8} \\
\hline \multirow[t]{5}{*}{ Strategies } & 2 & 4 & 16 & 3 & 9 & 11 & 22 & 8 & 8 & & \\
\hline & 3 & 5 & 20 & 14 & 42 & 7 & 14 & 0 & 0 & & \\
\hline & 4 & 9 & 36 & 10 & 30 & 7 & 14 & 0 & 0 & & \\
\hline & 5 & 5 & 20 & 9 & 27 & 10 & 20 & 2 & 2 & & \\
\hline & Total & 24 & 96 & 51 & 153 & 45 & 90 & 10 & 10 & & \\
\hline \multirow{6}{*}{$\begin{array}{l}\text { Cognitive } \\
\text { Strategies }\end{array}$} & 1 & 6 & 24 & 15 & 45 & 5 & 10 & 0 & 0 & \multirow[t]{6}{*}{399} & \multirow[t]{6}{*}{79.8} \\
\hline & 2 & 5 & 20 & 13 & 39 & 7 & 14 & 1 & 1 & & \\
\hline & 3 & 16 & 64 & 10 & 30 & 0 & 0 & 0 & 0 & & \\
\hline & 4 & 7 & 28 & 10 & 30 & 9 & 18 & 0 & 0 & & \\
\hline & 5 & 6 & 24 & 12 & 36 & 8 & 16 & 0 & 0 & & \\
\hline & Total & 40 & 160 & 60 & 180 & 29 & 58 & 1 & 1 & & \\
\hline \multirow{6}{*}{$\begin{array}{c}\text { Metacognitive } \\
\text { strategies }\end{array}$} & 1 & 7 & 28 & 8 & 24 & 11 & 22 & 0 & 0 & \multirow[t]{6}{*}{351} & \multirow[t]{6}{*}{70.2} \\
\hline & 2 & 4 & 16 & 8 & 24 & 10 & 20 & 4 & 4 & & \\
\hline & 3 & 5 & 20 & 7 & 21 & 14 & 28 & 0 & 0 & & \\
\hline & 4 & 2 & 8 & 9 & 27 & 12 & 24 & 3 & 3 & & \\
\hline & 5 & 10 & 40 & 10 & 30 & 6 & 12 & 0 & 0 & & \\
\hline & Total & 28 & 112 & 42 & 126 & 53 & 106 & 7 & 7 & & \\
\hline \multirow{6}{*}{$\begin{array}{l}\text { Affective } \\
\text { strategies }\end{array}$} & 1 & 11 & 44 & 11 & 33 & 4 & 8 & 0 & 0 & \multirow[t]{6}{*}{379} & \multirow[t]{6}{*}{75.8} \\
\hline & 2 & 5 & 20 & 10 & 30 & 11 & 22 & 0 & 0 & & \\
\hline & 3 & 5 & 20 & 12 & 36 & 7 & 14 & 2 & 2 & & \\
\hline & 4 & 4 & 16 & 12 & 36 & 10 & 20 & 1 & 1 & & \\
\hline & 5 & 8 & 32 & 9 & 27 & 9 & 18 & 0 & 0 & & \\
\hline & Total & 33 & 132 & 54 & 162 & 41 & 82 & 3 & 3 & & \\
\hline \multirow{5}{*}{$\begin{array}{c}\text { Social } \\
\text { strategies }\end{array}$} & 1 & 1 & 4 & 7 & 21 & 6 & 12 & 12 & 12 & \multirow[t]{5}{*}{322} & \multirow[t]{5}{*}{64.4} \\
\hline & 2 & 2 & 8 & 5 & 15 & 16 & 32 & 3 & 3 & & \\
\hline & 3 & 8 & 32 & 7 & 21 & 10 & 20 & 1 & 1 & & \\
\hline & 4 & 4 & 16 & 6 & 18 & 12 & 24 & 4 & 4 & & \\
\hline & 5 & 7 & 28 & 11 & 33 & 9 & 18 & 0 & 0 & & \\
\hline
\end{tabular}

CELTIC: A Journal of Culture, English Language Teaching, Literature \& Linguistics ISSN: 2356-0401, E-ISSN: 2621-9158, VOL. 6, NO. 1, June 2019. 


\begin{tabular}{|ccccccccccc|c}
\hline & Total & $\mathbf{2 2}$ & $\mathbf{8 8}$ & $\mathbf{3 6}$ & $\mathbf{1 0 8}$ & $\mathbf{5 3}$ & $\mathbf{1 0 6}$ & $\mathbf{2 0}$ & $\mathbf{2 0}$ & \multirow{2}{*}{ Compensation } \\
strategies & 1 & 13 & 52 & 9 & 27 & 4 & 8 & 0 & 0 & $\mathbf{3 8 3}$ & $\mathbf{7 6 . 6}$ \\
& 2 & 9 & 36 & 8 & 24 & 8 & 16 & 1 & 1 & & \\
& 3 & 7 & 28 & 14 & 42 & 5 & 10 & 0 & 0 & \\
& 4 & 10 & 40 & 13 & 39 & 3 & 6 & 0 & 0 & \\
& 5 & 2 & 8 & 5 & 15 & 12 & 24 & 7 & 7 & \\
& Total & $\mathbf{4 1}$ & $\mathbf{1 6 4}$ & $\mathbf{4 9}$ & $\mathbf{1 4 7}$ & $\mathbf{3 2}$ & $\mathbf{6 4}$ & $\mathbf{8}$ & $\mathbf{8}$ & \\
\hline
\end{tabular}

Note:

- Total score is the total of each score from Always, Often, Sometimes, and Never

- Means is the result of total score divided by the numbers of the items (5)

For the most common learning strategy scoring, the researcher gathered the twenty six (26) respondents' answer by using some criteria; Always (A), Often $(\mathrm{O})$, Sometimes $(\mathrm{S})$, and Never $(\mathrm{N})$. The point values of each statement were: Always: 4, Often: 3, Sometimes: 2, Never: 1.

Based on the result of the questionnaire, it shows that the biggest mean score was achieved by cognitive strategies with 79.8. It was followed by compensation strategies 76.6; affective strategies 75.8; metacognitive strategies 70.2; memory strategies 69.8 and last social strategies with 64.4 mean score. The cognitive strategy was common learning strategies in learning strategy employed by the learners.

\section{The Reasons in Choosing the Strategy}

The most common strategy used by the high-achiever students in learning vocabulary is cognitive strategy with the mean score of 79.8. During the interview, the respondents were asked about the reasons of choosing the strategy. There were twelve students who were categorized using cognitive strategies in learning vocabulary. The reasons of the twelve high-achiever students in choosing cognitive strategies are described as follows.

\section{a. Habitual strategy}

As mentioned by one of the high achiever students, PTR, the strategy was introduced by her mentor by taking notes and highlighting. She has been applied the strategy since then. The statement of the respondents was stated as follows;

"I apply that strategy when I was in elementary school and also when I was in junior high school I took a course and my mentor gives me a way to make leaning vocabulary easier by taking notes when my mentor gives new words and also always makes highlights in my notes. I still use the strategy until now."

b. The strategy is helpful

CELTIC: A Journal of Culture, English Language Teaching, Literature \& Linguistics ISSN: 2356-0401, E-ISSN: 2621-9158, VOL. 6, NO. 1, June 2019. 
During the interview, some high achiever students mentioned that based on the experience of employing cognitive strategy, they found cognitive strategy very helpful.

"I think the strategy is really helpful based on my experience and most of my friends have the same point with me when the lecturer delivered the material we usually take notes and try to imitate the lecturer so we know how to pronunciation the words correctly."

Also, student IR said in her interview that cognitive strategy helps her to learn new vocabulary that were found during the learning process. The statement of the respondents was stated as follows;

"Actually I do not fully aware I use those strategy but it helps me to learn the new vocabulary that I found"

Additionally, by employing certain cognitive strategy such as note-taking during learning vocabulary could help the high achiever student to learn English better. It happened to student SHN. The reason of her in choosing the strategy as stated as follows;

"I choose a cognitive strategy as the best strategy for my studying process. This strategy helps me to learn English better. When I feel difficult to memorize new vocabulary, I can take a note of new vocabulary, and I can use it in my daily activity so it feels easier to learn English".

Ultimately, not only helps high achiever students in learning English better but also in memorizing the new words. The statement of this were presented as follows;

"By using cognitive strategy, it helps me to memorize new words by using the meaning in Bahasa, and use it in my daily activity so it can help my mind to always remember the difficult words."

c. It is the easiest strategy and easy to apply

Four of twelve students employed cognitive strategy because it makes them easier to practice in learning process and cognitive strategy considered easy to apply.

One of the high achiever students, student NAR stated in her interview that cognitive strategy helps her to gain more vocabulary by taking note and doing highlight on the unfamiliar words. Besides, it also eases the student practice in learning process. The example is related to this condition were described in following interview extract.

CELTIC: A Journal of Culture, English Language Teaching, Literature \& Linguistics ISSN: 2356-0401, E-ISSN: 2621-9158, VOL. 6, NO. 1, June 2019. 
"I use cognitive strategy because it is easier for me to practice in learning process. When I was in third semester, one of the lecturer said that when you want to learn vocabulary you better to highlight the vocabulary and take a note, analyze that and you can practice it in learning and the end of your learning activity."

Meanwhile, students DK, MRF, and SIP said in their interview that cognitive strategy is an easy strategy to apply. Their statements about this condition are as follows;

"It is the easiest strategy that I have ever used."

"The reason why I use that strategy because I find it useful and it is really easy to apply and it helps a lot"

"I found the strategy is easy to apply and effective for me in improving my English skill."

d. To speak English well

One of the high achiever said that the reason in choosing cognitive strategy in learning vocabulary because in order to speak English well. The example is related to this condition were described in following interview extract.

"My reason to use the cognitive strategy in learning vocabulary in order to speak English well and I can increase my vocabulary."

e. The strategy is effective

Student NH, one of the high achiever student, employed cognitive strategy in learning vocabulary because it is effective for her. The high achiever's statement about this case presented as follows;

"Because I think it is very effective. I have a book which contains of many vocabulary that I have never know before. So, I started to write that book since in first grade or second grade of high school. When teacher explained some material that I do not know the meaning I directly asked them or look on the dictionary to find the meaning. It is very effective because I can read it many times and I can directly practice it."

f. The strategy is comfortable to use

Last reason of high-achiever students in choosing cognitive strategy as a tool to improve the vocabulary learning because the student is comfortable to employ the cognitive strategy. This case happened to student AF. The statement will presented as follows;

"I actually have no specific reason why I chose those strategies. It is just because I feel comfortable using those ways and it suitable for me."

CELTIC: A Journal of Culture, English Language Teaching, Literature \& Linguistics ISSN: 2356-0401, E-ISSN: 2621-9158, VOL. 6, NO. 1, June 2019. 


\section{Discussion}

Based on the questionnaire on strategy in learning strategy, it was found that all of the six learning strategies were employed by the high achiever students. The results of this current study described the most common strategy in learning vocabulary employed by high achiever students was cognitive strategy. The cognitive strategy took 79,8 by mean score as the most common strategy employed by the high achiever students.

According to Oxford (1990), cognitive strategy categorized as the most important strategy to apply during learning process. It involved practicing, receiving and sending messages, analyzing and reasoning, taking notes, summarizing, and highlighting. The statement above is suitable with the students' replies about cognitive strategy. Students uttered that cognitive strategy helped them learn vocabulary easily. One of the most popular reasons stated by the respondents is that by taking notes and highlighting the unfamiliar words helped them learning better, especially to memorize the difficult vocabulary by taking a note to write new information. Note-taking strategies is categorized as cognitive strategies (Gu and Johnson,1996). In addition, the other popular reason is because cognitive strategy considered easy to apply by them in learning vocabulary.

All in all, the result of this research explained that students who categorized as the high-achiever had their own typical way in learning vocabulary and used various strategy in assisting them in improving the English skill. Using strategy in learning knowledge especially in learning vocabulary is very important. Schumaker and Deshler (2006, as cited in Protheroe and Clarke, 2008) defined strategy as the approach to a task of an individual. Therefore, it involved how that individual thinks, acts while planning, executing, and performing the task and also the outcomes. Hence, strategy in learning vocabulary could affect students' achievement in learning process which could be divided into high achiever and low achiever students. Because of some difficulties that could be found during learning vocabulary, not all of students could develop their English skill. In contrast, there are also students who can learn English faster and easier rather than other even though they were taught by the same lecturer. In this case, they achieved GPA greater than others. Twelve out of twenty-six high achievers preferred to practice their English by using cognitive strategy such as taking notes, imitating what the teacher say, dictionary-use, analyzing, and other ways. Therefore, appropriate learning strategies would help the students to perform and master English well.

CELTIC: A Journal of Culture, English Language Teaching, Literature \& Linguistics ISSN: 2356-0401, E-ISSN: 2621-9158, VOL. 6, NO. 1, June 2019. 


\section{CONCLUSION}

This study found out that the most common strategy employed by high achiever students is cognitive strategy with mean score of 79.8.The high achiever students who preferred cognitive strategy believed that cognitive strategy really helps them to obtain new information about new words or vocabulary. Some of the students selected the strategies because by doing strategies such as note-taking, practicing, analyzing and summarizing, highlighting, imitating teacher, finding difficult words in dictionary could assist them to improve the English skill such as reading, writing, speaking, listening.

\section{REFERENCES}

Alqahtani, M. (2015). The importance of vocabulary in language learning and how to be taught. International Journal of Teaching and Education, 3(3), 21-34.doi: 10.20472/te.2015.3.3.002

Angrosino, M. V. (2007). Naturalistic observation. California: Left Coast Press.

Arikunto, S. (2010). Prosedur penelitian suatu pendekatan praktik. Jakarta: Rineka Cipta.

Boonkongsaen, N. (2012). Factors affecting vocabulary learning strategies: A synthesized study. Naresuan University Journal,20(2), 45-53. Retrieved from http://www.journal.nu.ac.th/NUJST/article/view/6/7

Brown, H. D. (2007). Principles of language learning and teaching ( $5^{\text {th }}$ ed.) New Jersey: Pearson Education.

Burrow, J., Dooley, M., Wright, T., \& DeClou, L. (2012). A report on the postsecondary decisions of high-achieving students in Ontario. Toronto: Toronto Higher Education Quality Council of Toronto.

Creswell, J. W. (2014). Research design: Qualitative, quantitative, and mixed methods approaches. London: Sage Publication, Inc.

Gu, Y., \& Johnson, R. K. (1996). Vocabulary learning strategies and language learning outcomes. Language Learning 46(4), 643-679.DOI:

10.5539/ass.v12n10p174

Hardan, A. A. (2013). Language learning strategies: A general overview. Procedia-Social and Behavioral Sciences. doi: 106. 10.1016/j.sbspro.2013.12.194. 
Hashemi, Z., \& Hadavi, M. (2015). Investigation of vocabulary learning strategies among EFL Iranian medical sciences students. Procedia-Social and Behavioral Sciences. doi: 192. 629-637. 10.1016/j.sbspro.2015.06.110.

Nation, I.S.P. (2001). Learning vocabulary in another language. Cambridge: Cambridge University Press.

Oxford, R. L. (1990). Language learning strategies : What every teacher should Know. Australia: Heinle Cengage Learning.

Protheroe, N., \& Clarke, S. (2008). Learning strategies as a key to student success. Principal. Retrieved from https://www.naesp.org/sites/default/files/resources/2/Principal/2008/NDp33.pdf

Universitas Muhammadiyah Malang. (2011). Peraturan Akademik No 15. Malang.

Waskito, A. (2005). A study on strategies of learning vocabulary employed by English department students at Muhammadiyah university of Malang .Bachelors Degree (S1) Theses, University of Muhammadiyah Malang, Malang.

Zohar, A., Degani, A., \& Vaaknin, E. (2001). Teachers' beliefs about low achieving students and higher order thinking. Teaching and Teacher Education. Retrieved from(http://www.sciencedirect.com/science/article/pii/S0742051X010000 75) 